\title{
FAKTOR PENDUKUNG DAN PENGHAMBAT KEBIJAKAN JANGKA PANJANG PEMERINTAH KABUPATEN KEDIRI DALAM PEMBANGUNAN CENTRAL BUSINESS DISTRICT
}

\section{Supporting And Resistance Factors Of Government Long Term Policy In Kediri District In Development Central Business District}

\author{
Haryanto ${ }^{1}$ \\ ${ }^{1}$ FISIP Universitas Kadiri \\ e-mail :1Haryanto@unik-kediri.ac.id
}

\begin{abstract}
Abstrak
Pemerintah Kabupaten Kediri membentuk ikon Kabupaten Kediri dengan membangun Simpang Lima Gumul dan Monumen. Dengan demikian, diharapkan terdapat investasi pada daerah Simpang Lima Gumul karena merupakan jalan dan lokasi strategis. Peneletian ini dianalisa menggunakan teori peran pemerintah dan kebijakan publik. Metode penelitian pada jurnal ini menggunakan metode kualitatif deskriptif. CBD diadakan dengan sistem multiyears dan berkesinambungan, artinya dilakukan anggaran per tahun. Proyeknya dari pembebasan sampai selesai dari tahun 2002-2012. Tahap proyeknya meliputi pembebasan tanah pada tahun 2002-2009, pembangunan monumen, pembangunan jalan raya, dan tahap ke empat pembangunan fasilitas umum seperti terminal, bank daerah, pasar tugu pada hari minggu dan kantor imigrasi. Sedangkan pembangunan Hall baru selesai tahun 2012. Hal ini masih diperlukan investor untuk pembangunan $\mathrm{CBD}$ karena keterbatasan dana dari pemerintah. Faktor pendukung dalam kebijakan pembangunan CBD yaitu adanya kerjasama dengan kantor dagang Jerman, Perancis dan jejaring lainnya. Faktor Penghambat dari pembentukan CBD yaitu lokasi perdagangan dan perindustrian yang belum terbentuk, masih sedikitnya unit usaha yang dibangun di area Simpang Lima Gumul.
\end{abstract}

Kata Kunci: Pemerintah Daerah; Kebijakan; Central Business District

\begin{abstract}
The Government of Kediri Regency formed the icon of Kediri Regency by building Simpang Lima Gumul and Monuments. Thus, it is expected that there will be investments in the Simpang Lima Gumul area because it is a strategic road and location. This study was analyzed using the theory of the role of government and public policy. The research method in this journal uses descriptive qualitative methods. $C B D$ is held in a multi-year and continuous system, meaning that the budget is carried out annually. The project is from exemption until completion from 20022012. The project phase includes land acquisition in 2002-2009, construction of monuments, construction of highways, and the fourth phase of construction of public facilities such as terminals, regional banks, the monument market on Sundays and the immigration office. While the construction of the new Hall was completed in 2012. This is still needed by investors for $C B D$ development because of limited funding from the government. Supporting factors in the CBD development policy are cooperation with German, French and other networks. Inhibiting Factors of CBD formation, namely trade and industry locations that have not yet been established, there are still few business units built in the Simpang Lima Gumul area.
\end{abstract}

Keywords: Local Government; Public Policy; Central Business District

\section{A. PENDAHULUAN}

PDRB ADH dan Pendapatan Perkapita Kabupaten Kediri belum dapat menyaingi kotakota besar. Hal ini disebabkan karena sempitnya lapangan pekerjaan di Kabupaten Kediri dan masih minimnya fasilitas umum. Kehidupan kota yang serba modern menjadi daya tarik yang kuat bagi penduduk Kabupaten Kediri untuk melakukan urbanisasi.

Dengan adanya PDRB ADH dan Pendapatan Perkapita yang masih rendah antara daerah satu dan daerah lainnya di Jawa Timur, maka diperlukan peranan pemerintah daerah 
dalam mengatasi kesenjangan pembangunan daerah dan pemerataan pendapatan. Sesuai amanat UUD 1945, pemerintah daerah berwenang untuk mengatur dan mengurus sendiri urusan pemerintahan menurut asas otonomi dan tugas pembantuan. Pemberian otonomi luas kepada daerah diarahkan untuk mempercepat terwujudnya kesejahteraan masyarakat melalui peningkatan pelayanan, pemberdayaan, dan peran serta masyarakat. Disamping itu melalui otonomi luas, daerah diharapkan mampu meningkatkan daya saing dengan memperhatikan prinsip demokrasi, pemerataan, keadilan, keistimewaan dan kekhususan serta potensi dan keanekaragaman daerah dalam sistem Negara Kesatuan.

Pemerintah daerah dalam rangka meningkatkan efisiensi dan efektivitas penyelenggaraan otonomi daerah, perlu memperhatikan hubungan antar susunan pemerintahan dan antar pemerintah daerah, potensi dan keanekaragaman daerah. Aspek hubungan antar wewenang memperhatikan kekhususan dan keragaman daerah dalam negara kesatuan Republik Indonesia. Aspek hubungan keuangan, pelayanan umum, pemanfaatan sumber daya alam dan sumber daya lainnya dilaksanakan secara adil dan selaras. Disamping itu perlu diperhatikan pula peluang dan tantangan dalam persaingan global dengan memanfaatkan perkembangan ilmu pengetahuan dan teknologi. Agar mampu menjalankan perannya tersebut, daerah diberikan kewenangan yang seluas-luasnya disertai dengan pemberian hak dan kewajiban menyelenggarakan otonomi daerah dalam kesatuan sistem penyelenggaraan pemerintahan negara.

Pada tingkat daerah, penyelenggaraan fungsi pemerintahan menjadi tugas dan kewajiban kepala daerah beserta aparat yang ada di bawahnya. Undang-undang Nomor 32 Tahun 2004 tentang Pemerintah Daerah menyebutkan tugas kepala daerah salah satunya adalah memimpin penyelenggaraan pemerintah daerah berdasarkan kebijakan yang ditetapkan bersama Dewan Perwakilan Rakyat Daerah. Dalam penyelenggaraan pemerintah daerah, terdapat perbedaan pengelolaan dibanding dengan sektor privat. Perbedaan ini terutama disebabkan adanya perbedaan karakteristik diantara keduanya.

Karakteristik organisasi nonprofit adalah ketiadaan ukuran laba, adanya pertimbangan pajak dan hukum, kecenderungan menjadi organisasi jasa, kendala yang lebih besar pada tujuan dan sasaran, kurang tergantung pada klien untuk dukungan keuangan, dominasi profesional, perbedaan dalam tata kelola, pentingnya pengaruh politik, dan tradisi pengendalian manajemen yang kurang. Dari karakteristik tersebut, ketiadaan motif laba merupakan ciri yang utama pada organisasi sektor publik. Adanya perbedaan karakteristik tersebut menyebabkan konsep dan praktik manajemen sektor privat tidak dapat diterapkan sepenuhnya pada sektor publik. Meskipun demikian tidak berarti bahwa sektor publik tidak dapat dilakukan dengan manajemen kewirausahaan. Menurut Osborne dan Gabler dalam (Asmoko, 2009:2) terdapat sepuluh prinsip dalam menerapkan kewirausahaan pada pemerintahan yaitu pertama, pemerintahan kewirausahaan mendorong kompetisi diantara penyedia pelayanan. Kedua, pemerintah mendayagunakan masyarakat dengan mendorong pengendalian masyarakat. Ketiga, ukuran kinerja adalah outcome bukan input. Keempat, Pemerintahan dikendalikan oleh tujuannya atau misinya bukan oleh aturan dan regulasi. Kelima, pemerintah mendefinisikan kliennya sebagai konsumen. Keenam, pemerintah berusaha untuk mencegah timbulnya masalah daripada mencari solusi setelah masalah terjadi. Ketujuh, pemerintah memanfaatkan tenaganya untuk menghasilkan uang tidak sekedar membelanjakan. Kedelapan, pemerintah mendorong desentralisasi wewenang. Kesembilan, pemerintah lebih suka pada mekanisme pasar daripada mekanisme birokrasi. Kesepuluh, pemerintah tidak menfokuskan pada penyediaan pelayanan publik tapi sebagai katalisator semua sektor.

Hood (1995) dalam (Asmoko, 2009:3) mempertimbangkan sistem manajemen sektor publik dalam bentuk dua elemen pokok yaitu tingkat perbedaan dari sektor privat dan tingkat dari aturan operasi untuk menjadi penyangga terhadap kebijakan politis dan manajerial. Menggunakan dua unsur pokok ini, Hood mengidentifikasi tujuh doktrin yang mendasari new public management (NPM) yaitu pertama, penguraian sektor publik menjadi unit korporasi di organisasi berdasarkan produk. Kedua, ketentuan persaingan didasarkan kontrak, dengan pasar internal dan kontrak bersyarat. Ketiga, menekankan pada gaya sektor privat mengenai praktik manajemen. Keempat, lebih menekankan pada disiplin dan penghematan dalam penggunaan sumber daya. Kelima, lebih menekankan pada manajemen puncak yang bervisi. Keenam, standar dan ukuran kinerja dan keberhasilan dapat diukur secara jelas. Ketujuh, penekanan lebih besar pada output. Doktrin satu 
sampai dengan empat menyangkut teknik NPM dalam mengurangi perbedaan administrasi sektor publik dibanding dengan sektor privat. Doktrin lima sampai dengan tujuh menyangkut teknik NPM dalam mengurangi aturan sektor publik dan meningkatkan ketersediaan kebijaksanaan bagi manajer sektor publik.

Manajemen Strategis merupakan istilah yang sangat dekat dengan teori ekonomi dan atau bisnis atau manajemen bisnis. Akan tetapi, seiring dengan kemajuan ilmu pengetahuan dan teknologi saat ini, manajemen strategis sudah mulai banyak dan biasa diaplikasikan pada sektor-sektor publik. Sektor publik menginginkan keberhasilan yang dicapai dalam organisasi bisnis berupa efektivitas dan efisiensi dapat terwujud pada organisasi publik/pemerintahan. Sebelum membahas lebih lanjut tentang manajemen strategis, terlebih dahulu kita harus mengenal apa itu manajemen strategis. Banyak definisi tentang manajemen strategi yang dikemukakan oleh para ahli. Definisi tersebut terdapat perbedaan dan persamaan satu dengan yang lainnya serta terus mengalami perkembangan sesuai dengan sudut pandang masing-masing. Berikut ini akan dikemukakan beberapa definisi tentang manajemen strategis. Arnoldo C Hax dan Nicholas S Majluk dalam bukunya "Strategic Management" mendefinisikan manajemen strategis sebagai cara menuntun organisasi/perusahaan pada sasaran utama pengembangan nilai korporasi, kapabilitas manajerial, tanggung jawab organisasi, dan sistem administrasi yang menghubungkan pengambilan keputusan strategis dan operasional pada seluruh tingkat hierarki, dan melewati seluruh lini bisnis dan fungsi otoritas perusahaan. (Nugraha 2014). Desentralisasi pengelolaan pemerintahan daerah yang disertai adanya otonomi yang luas dan tata kelola pemerintahan yang mengacu pada konsep kewirausahaan dan manajemen publik baru menyebabkan pentingnya manajemen strategis pada pengelolaan pemerintah daerah. Weschsler dan Berry mengemukakan manajemen strategis dipandang sebagai alat penting di negara bagian karena beberapa alasan. Pertama, model manajemen strategis menjanjikan pendekatan terstruktur, berurutan untuk mengelola kekomplekan tinggi, masalah tidak berurutan yang dihadapi negara bagian (Olsen dan Eadie, 1982) dalam (Asmoko, 2009:4). Kedua, manajemen strategis dipandang oleh politisi dan pemimpin manajerial sebagai mekanisme untuk memasukkan perspektif rasional-teknik dalam proses pemerintah. Ketiga, manajemen strategis menawarkan kebijakan yang lebih besar dan mengijinkan untuk mengembangkan dasar untuk pengambilan keputusan. Keempat, manajemen strategis menarik bagi pejabat pemerintah negara bagian karena telah digunakan secara luas di sektor privat dan diadopsi oleh pemerintah dipandang mendorong praktik yang paling baik dari keberhasilan organisasi bisnis.

Pada penelitian ini,peneliti tertarik untuk membahas faktor pendukung dan penghambat kebijakan jangka panjang pemerintah kabupaten kediri dalam pembangunan central business district. Adapun rumusan masalah sebagai berikut:

1. Bagaimana tujuan dan kebijakan jangka panjang dalam Central Business District?

2. Bagaimana faktor pendukung dan penghambat kebijakan jangka panjang pemerintah kabupaten kediri dalam pembangunan Central Business District?

\section{B. LANDASAN TEORITIS}

\section{1) Pemerintah Daerah}

Pengertian pemerintah lokal menurut (Sady, 2002) dalam (Indardi, 2008:14) adalah: “.... a political subdivision of a nation or state which contituted by law and has substantial control over local affairs which has governing body elected or otherwise locally selected". Sementara itu, Humes dan Marfin dalam (Indardi, 2008:14) secara ringkas mengartikan pemerintah daerah sebagai "an infrasouvereign geographic subdivision of a souvereign nation or quasi-souvereign state providing services at the local level" (Humes \& Marfin, 1961). Sedangkan Iglesias mengkonseptualisasikan desentralisasi sebagai desentralisasi politik yang bentuknya adalah daerah-daerah otonom, dan desentralisasi administratif yang menghasilkan local state government dalam bentuk wilayah-wilayah administratif.

Pandangan tradisional tentang peran pemerintah selalu mengacu pada apa yang diungkapkan oleh Adam Smith dalam bukunya yang terkenal "Wealth of Nations" bahwa "pemerintah memiliki tugas melindungi masyarakat dari pelanggaran dan invasi dari anggota masyarakat lainnya serta bertugas menegakkan administrasi keadilan secara pasti". Pandangan ini menempatkan peran pemerintah secara terbatas hanya pada pertahanan, pengadilan dan polisional. (Starling, 1998 dalam Muluk, 2005:57).

\section{2) Kebijakan Publik}

Pengertian kebijakan publik menurut Dye dalam Leo (2008:7), bahwa “Kebijakan publik adalah apa yang dipilih oleh pemerintah untuk 
dikerjakan atau tidak dikerjakan". Pendapat yang lain lagi mengenai pengertian dari kebijakan publik ini disampaikan Kartasasmita (1997: 142) dalam Widodo (2017: 12-13) Kebijakan merupakan upaya untuk memahami dan mengartikan (1) apa yang dilakukan (atau tidak dilakukan) oleh pemerintah mengenai suatu masalah, (2) apa yang menyebabkan atau yang mempengaruhi, dan (3) apa pengaruh dan dampak dari kebijakan publik tersebut.

\section{C. METODE PENELITIAN}

Sejalan dengan definisi tersebut, Kirk dan Miller dalam (Moleong 2008:4) mendefinisikan bahwa "penelitian kualitatif adalah tradisi tertentu dalam ilmu pengetahuan sosial yang secara fundamental bergantung dari pengamatan pada manusia baik dalam kawasannya maupun dalam peristilahannya".

Dari kedua pendapat tersebut di atas dapat diambil kesimpulan bahwa penelitian kualitatif adalah penelitian yang bergantung dari pengamatan pada manusia dan menghasilkan data deskriptif berupa kata-kata tertulis atau lisan dan perilaku dari orang-orang yang dapat diamati.

Berdasarkan teori tentang penelitian kualitatif tersebut, peneliti berkeyakinan untuk menggunakan metode penelitian deskriptif, karena metode penelitian ini memusatkan pada deskripsi yang berupa kalimat-kalimat yang memiliki arti mendalam yang berasal dari informan dan perilaku berbagai hal yang ada relevansinya dengan pelaksanaan Pembangunan Central Business District di Simpang Lima Gumul Kabupaten Kediri. Peneliti tidak memberikan treatment atau perlakuan terhadap objek. Objek dibiarkan apa adanya seperti kondisi aslinya.

Dalam penelitian kualitatif, peneliti merupakan instrumen utama yang menentukan tinggi rendahnya kualitas hasil penelitian. Oleh karena itu, yang sangat diutamakan dalam penelitian ini adalah kemampuan peneliti dalam menerjemahkan data yang diperoleh dari hasil wawancara, observasi, arsip atau dokumen.

\section{PEMBAHASAN}

\section{1) Tujuan dan Kebijakan Jangka Panjang dalam Central Business District.}

a) Tujuan Jangka Panjang dalam Central Business District Kabupaten Kediri

Pembangunan Simpang Lima Gumul mempunyai tujuan jangka panjang. Tujuan jangka panjang tersebut tertulis dalam masterplan pembangunan Simpang Lima Gumul tahun 2002.
Pemerintah Kabupaten Kediri dengan pembangunan Simpang Lima Gumul mempunyai target untuk membentuk Pusat Kota Baru atau Central Business District. Selama ini, fasilitas yang sudah dibangun meliputi, monumen, pusat perdagangan, terminal, convention hall, jalan raya, bank daerah, kantor imigrasi, pos polisi dan satpol PP dan pasar tugu. Selain itu, sekarang ini terdapat waterpark Gumul Paradise Island dari sektor swasta yang berinvestasi di area Simpang Lima Gumul. Fungsi dari pembangunan infrastruktur dan fasilitas yang sudah ada tersebut sebagai berikut:

\section{1). Monumen}

Monumen Simpang Lima Gumul adalah salah satu ikon baru dari objek wisata lokal yang ada di kediri. Terletak di persimpangan arah selatan ke Wates/Pesantren, Timur Ke Gurah Utara ke pagu - arah timur laut ke Pare - dan arah ke Barat ke Kota Kediri. Tujuan awal dibangun Simpang Lima Gumul (SLG) adalah sebagai sentra ekonomi baru di Kabupaten Kediri. Sehingga diharapkan roda perekonomian Kediri makin maju. Sebagai ikon di bangun monumen mirip L'Arch de Triomphe Paris.

\section{2). Jalan Raya}

Pemerintah membangun jalan raya berbentuk Simpang Lima. Tujuan Pembangunan jalan tersebut selain untuk menghindari kemacetan, juga untuk menarik investor agar beinvestasi di dekat jalan tersebut. Pembangunan jalan raya pada Simpang Lima Gumu dapat mengundang keramaian, hal ini diharapkan dapat mengawal untuk tujuan akhirnya yaitu akan terbentuk pusat kota yang ramai.

\section{3). Kantor Imigrasi}

Pada area Simpang Lima Gumul terdapat Kantor Imigrasi. Penempatan Kantor Imigrasi tersebut berkaitan dengan letak yang strategis dari Simpang Lima Gumul. Jika terdapat investor yang ingin melakukan investasi maka akan dipermudah dengan adanya kantor imigrasi yang dekat untuk investor asing dalam mengurus surat imigrasinya.

\section{4). Pos Polisi dan Satpol PP}

Pada fasilitas umum yang sering terdapat keramaian, seringkali terjadi hal yang mengancam keamanan karena banyak pengunjung dengan berbagai kepentingan. Untuk menertibkan keramaian pada Simpng Lima Gumul pemerintah membangun pos Polisi dan 
Satpol PP. Selama ini kondisi keamanan Simpang Lima Gumul masih terkondisikan. Pemerintah akan terus berupaya menjaga keamanannya, karena keamanan juga menjadi kunci penting sebagai pertimbangan investor dalam menanamkan modalnya pada area Simpang Lima Gumul.

\section{5).Pasar Tugu}

Pasar ini adalah proyek dari Pemda Kabupaten Kediri guna meningkatkan kunjungan ke SLG. Oleh karenanya stand disana adalah gratis.. Pasar ini terletak di timur Kediri Waterpark aka Gumul Paradise Island. Disana terdapat beberapa produk -produk kerajinan dari kayu, tempurung kelapa yang biasa kita temui di daerah wisata seperti Jogja dan Bali. Di Kediri terdapat kerajinan mug, sendok, sutil, alat pijat dari kayu dan tempurung kelapa dibuat di Kecamatan Grogol. Aksesoris dari manik-manik seperti gelang, konde, bros dibuat di Kecamatan Sukorejo Ds. Tepus. Sepatu batik dan aneka rajutan dari Kecamatan Pagu.

\section{6). Pusat Perdagangan}

Lokasi dari trade centre ini berada di bawah tanah monumen Simpang Lima Gumul. Rencananya, di ruang bawah tanah tersebut dibangun mall, pusat grosir dan pusat pameran barang-barang produksi khas Kabupaten Kediri. Di basement saat ini mulai dibangun ruang serbaguna, ruang yang direncanakan untuk tempat penjualan aneka souvenir dan produk unggulan asli Kabupaten Kediri. Lalu ruang pertemuan di gedung utama serta auditorium di lantai berikutnya. Monumen itu juga memiliki tiga akses jalan bawah tanah terhubung ke tempat parkir.

\section{7). Convention Hall (Aula Pertemuan)}

Lokasi gedung pertemuan ini berada di selatan monumen SLG. Convention hall ini dibangun dua lantai dengan berbagai fasilitas layaknya sebuah gedung pertemuan. Rencananya covention hall ini akan digunakan untuk berbagai kegiatan pertemuan seperti seminar, penyuluhan dan pertemuan dengan Kepala Daerah. Dengan adanya gedung pertemuan di CBD ini akan meningkatkan perekonomian daerah, sebab gedung ini akan disewakan dengan kapasitas lebih dari 500 orang.

\section{8). Bank Daerah}

Salah satu fasilitas di CBD SLG adalah Bank Daerah Kabupaten Kediri. Bank ini merupakan sarana untuk membantu mengelola keuangan daerah. Prinsip dari bank daerah ini hampir sama dengan bank perkreditan rakyat. Masyarakat Kabupaten Kediri akan dibantu dengan peminjaman modal untuk membantu usaha yang mereka jalankan.

\section{9). Sub Terminal Gumul}

Transportasi merupakan sarana penting dalam menunjang perekonomian suatu daerah. Pemkab Kediri sangat memahami hal tersebut. Pembangunan Subterminal Gumul merupakan upaya untuk menunjang perekonomian daerah Kabupaten Kediri. Di samping terminal dibangun Dinas Perhubungan Kabupaten Kediri. Diharapkan dengan adanya Dinas Perhubungan yang dekat akan lebih memperlancar koordinasi transportasi di Kabupaten Kediri.

\section{0). Waterpark (Gumul Paradise Island)}

Kawasan Simpang Lima Gumul merupakan kawasan yang diproyeksikan sebagai pusat perdagangan yang bisa memperkenalkan dan menjual produk masyarakat dari home industry. Salah satu cara untuk menjadikan kawasan ini menjadi ramai oleh pengunjung adalah dengan membangun sarana pariwisata. Keberadaan Gumul Paradise Island ini tentu saja akan menarik masyarakat Kediri dan sekitarnya untuk berkunjung ke kawasan SLG. Keberadaan Gumul Paradise Island memberikan dampak positif bagi masyarakat yang tinggal di sekitar kawasan SLG, salah satunya adalah mengurangi pengangguran. Berbagai peluang usaha dapat tercipta, seperti menyediakan jasa penitipan kendaraan/parkir serta menjual berbagai makanan, barang ataupun oleh-oleh bagi pengunjung.

CBD dibangun oleh pemerintah untuk kepentingan masyarakat. Masyarakat dapat menggunakannya sebagai sarana rekreasi dan pengetahuan tentang icon wilayahnya. Selanjutnya dapat dijelaskan tujuan pembangunan CBD sebagai berikut:

(1) Meningkatkan PAD dan retribusi pajak

Pada saat ini, pembangunan Simpang Lima Gumul dapat menambahkan pajak dari kunjungan masyarakat melalui retribusi parkir sebesar 3000 rupiah untuk parkir mobil dan 1000 rupiah untuk parkir motor. Selanjutnya, untuk memasuki monumen tidak dikenakan biaya. Pada investai pembangunan fasilitas umum tidak dikenai pajak Bumi dan Bangunan serta pajak 
hiburan. PAD bertambah dari tarif awal investasi. Pada PT. Panorama Wisata Sejahtera investasi awal sebesar 10 milyar diluar tanah dan bangunan.

(2) Meningkatkan kesejahteraan rakyat lewat home industry dan UMKM.

Pada simpang lima gumul terdapat pusat perdagangan dibawah tanah. Ini adalah tempat yang digunakan untuk pameran home industry dan UMKM, selain itu juga terdapat pasar tugu untuk pameran home industry dan UMKM, pada waterpark Gumul Paradise Island juga menjual oleh-oleh dari UMKM Kabupaten Kediri. Pemerintah Kabupaten Kediri memberikan fasilitas untuk UMKM mempromosikan produknya melalui adanya event-event dan tempat khusus pada Simpang Lima Gumul.

(3) Memajukan sektor ekonomi dan pariwisata Kabupaten Kediri

Kabupaten Kediri menambahkan fasilitas pariwisata dalam pembangunan Simpang Lima Gumul. Selain tempat wisata seperti Gunung Kelud, air terjun Dholo, gereja puh sarang dan tempat wisata lainnya. Simpang Lima Gumul sebagai ikon yang menarik bagi masyarakat kabupaten kediri dan masyarakat daerah lain.

\section{(4) Mengurangi pengangguran}

Keberadaan Simpang Lima gumul didesain dengan fasilitas awal yang dibangun pemerintah kabupaten kediri, pada akhirnya diharapkan banyak investor yang masuk. Investor tesebut diharapkan dapat mengambil tenaga kerja dari masyarakat sekitar wilayah Simpang Lima Gumul. Selain itu terdapat pasar tugu pada minggu pagi, pasar ini dapat menambah pendapatan bagi penduduk sekitar SLG. SLG akan dijadikan sebagi ciri khas dari Kabupaten Kediri karena tidak semua daerah mempunyai Simpang Lima selain Kota Semarang. Simpang Lima Gumul sebagai Ikon Kabupaten Kediri. Sebelum adanya SLG, Kabupaten Kediri masih belum mempunyai Ikon. Ikon tersebut diharapkan dapat menjadi daya tarik untuk untuk wisatawan maupun investor. Selain itu Simpang Lima Gumul dapat dijadikan pusat Kota, dimana kantor pemerintah juga dekat dengan lokasi Simpang Lima Gumul.

\section{(5) Sebagai pusat perekonomian.}

SLG direncanakan akan menjadi CBD (Central Business District) dengan demikian, pusat perekonomian akan berada pada SLG dan menjadi daya tarik bagi perekonomian yang diharapkan akan tercipta pertumbuhan ekonomi.

(6) Memperlancar arus lalu lintas melalui SLG.

Dengan desain Simpang Lima Gumul yang mempunyai lima arah, maka kemacetan lalu lintas akan terurai melalui lima arah tersebut. Nantinya jika daerah ini ramai maka kemacetan akan dapat dihindari. SLG pada lima arahnya menghubungkan antara kabupaten Kediri, Wates dan daerah Pare.

Pada pembangunan Simpang Lima Gumul, Pemerintah Kabupaten Kediri mengharapkan capaian untuk terciptanya Central Business District (Pusat Kota Baru). Central Business District merupakan simbol kekuatan kehidupan sosial ekonomi suatu kota yang menunjukan tingkat intensitas interaksi antara orang dan aktivitasnya pada suatu kawasan tertentu yang relatif kecil, tetapi dapat menciptakan suatu kondisi yang dinamis. Pada umumnya CBD terletak pada pusat kota yang merupakan kawasan tertua dari pusat kota. Sebagai wadah kegiatan ekonomi CBD berkaitan dengan fungsi-fungsi sebagai berikut :

- Tempat pelaksanaan transaksi atau lingkungan kerja.

- Pasar tenaga kerja, sejumlah besar tenaga kerja dengan keahlian yang berbeda-beda dapat dijumpai di pusat keuangan pasar kredit.

- Fasilitas perbelanjaan skala tinggi merupakan lain dari prasarana yang tersedia di pusat kota.

Dengan adanya fasilitas yang sudah terbangun seperti monumen, pusat perdagangan, terminal, convention hall, jalan raya, bank daerah, kantor imigrasi, pos polisi dan satpol PP dan pasar tugu. Pemerintah masih memerlukan pembangunan berupa grosir, hotel, mall dan pusat hiburan indoor, perumahan, pujasera, ruang terbuka hijau, ruko, taman air, taman kota, fasilitas umum. Grosir tersebut diperlukan untuk menarik pusat grosir yang sebelumnya ada di Surabaya, diharapkan barang dagangan untuk kabupaten kediri semakin murah, hotel diperlukan untuk sarana bagi pebisnis yang ada di luar kota, taman air, ruang terbuka hijau, dan taman kota diperlukan untuk keindahan dan melestarikan lingkungan disamping pembangunan. Mall dan pujasera masih diperlukan karena untuk menarik mall yang ada di kota Kediri, selama ini masyarakat Kabupaten Kediri masih belum mempunyai mall. Sementara 
pembangunan perumahan diharapkan untuk menjadi pengisi keberadaan penduduk yang semakin dekat dengan pusat daerah.

Upaya Pemerintah Kabupaten Kediri dalam pembangunan CBD merupakan salah satu arti peran pemerintah daerah. Pemerintah daerah bertugas untuk membangun daerahnya. Seperti yang dikatakan Wajong (1975) dalam (Indardi, 2008:20), menyebut istilah pemerintah daerah (local authority) sebagai badan yang menjalankan pemerintahan daerah sedangkan pemerintahan daerah (local government) adalah kegiatan yang dilakukan oleh pemerintah daerah. Terdapat kewenangan yang diberikan kepada daerah, sehingga daerah dapat menggali potensi yang ada untuk membangun daerah sesuai dengan kehendak masyarakatnya.

Pemerintah Kabupaten Kediri berupaya untuk memenuhi kebutuhan masyarakat. Di luar hal tersebut dipenuhi sendiri oleh masyarakat dengan berinteraksi satu sama lain dalam lembaga pasar. Akan ada equilibrium sebagai titik temu antara permintaan dan penawaran sehingga setiap pihak akan mencapai kepuasan maksimum. Kondisi tersebut saat ini tentu tidak dapat dipertahankan lagi karena kelemahan mekanisme pasar dalam memberikan pelayanan publik yang efisien, adil, serta memenuhi seluruh kebutuhan masyarakat yang terus berkembang dan menuntut untuk dipenuhi. (Starling, 1998 dalam Muluk 2005:57). Sehingga pemerintah Kabupaten Kediri membangun CBD untuk mengundang investor dalam penyediaan sarana dan prasarana atau fasilitas publik. Pada akhirnya jika master plan itu tercapai, maka kebutuhan masyarakat pada fasilitas umum akan terpenuhi. Selama ini pada penyediaan hiburan, masyarakat Kabupaten Kediri masih bergantung pdaa Kota Kediri. Hiburan tersebut seperti mall, bioskop dan pujasera.

Pemerintah Kabupaten Kediri berupaya megatasi kegagalan pasar yang akan terjadi jika master plan sudah terbentuk maupun persiapannya dari sekarang terhadap penanaman modal dengan membentuk kantor penanaman modal. Lembaga ini dibentuk untuk menanggulangi kegagalan pasar. Kegagalan pasar tersebut dapat berupa natural monopoly, dan externality, kegagalan pasar bebas untuk menyediakan public goods secara memadai karena sulitnya untuk memisahkan pihak yang membayar meski menikmati pelayanan yang sama. Kondisi tersebut memicu kesulitan pihak yang menawarkan pelayanan untuk memecahkan free rider problem. (Starling, 1998 dalam Muluk 2005:57-58).

Menghadapi persoalan kegagalan pasar tersebut, masyarakat menuntut pemecahan dari pemerintah. Peran pemerintah diperluas tidak lagi sekedar pertahanan, pengendalian dan polisional belaka. Selanjutnya, Musgrave (dalam Muluk, 2005:57-58) Untuk mengatasi kegagalan mekanisme pasar, maupun kegagalan pemerintah tersebut, (Osborn dan Geabler 1992 dalam Muluk, 2005:59) dalam bukunya yang terkenal yaitu Reinventing Government .

Kantor penanaman modal bertugas untuk mengatur pasar yang akan tercipta pada CBD melalui regulasi dan perijinan. Selain itu, keberadaan Kantor Penanaman modal dengan tangan terbuka memberi kesempatan pada penanam modal dengan mempermudah perijinan dan pembuatan regulasi tentang penanaman modal pada pemerintah daerah. Di dalam tugas KPM tersebut terdapat pelaksanaan Reinventing Government dari konsep Osborn dan Ted Geabler. KPM bekerjasama dengan swasta dalam pengaturan pasar. Peran pemerintah yang tidak dominan, namun berupaya memberi kesempatan seluas-luasnya pada swasta. Pemerintah membuat regulasi yang mempermudah swasta dalam berinovasi dan tumbuh. Sesuai dengan prinsipnya, Steering rather than doing.

Pembangunan CBD dibutuhkan investor untuk pembangunan Proyek pembangunan grosir, hotel, mall dan pusat hiburan indoor, perumahan, pujasera, ruang terbuka hijau, ruko, taman air, taman kota, fasilitas umum. Hal ini dikarenakan keterbatasan dana dari pemerintah maka diperlukan kemitraan dengan pihak swasta dalam penyediaan fasilitas umum lainnya.

\section{Pemerintah Kabupaten Kediri} memberikan kesempatan kepada semua investor untuk menanamkan modalnya pada Central Business District. Pemerintah Kabupaten Kediri tidak tebang pilih dalam menentukan investor. Sekarang ini masih banyak sekali dibutuhnkan investor sesuai master plan. Investor di luar master plan akan dipertimbangkan kembali. Sekarang ini dibutuhkan investasi dari PT. Alfa mart atau Indomaret jika mereka bersedia menjadi investor.

b) Kebijakan Jangka Panjang Pemerintah Kabupaten Kediri dalam Central Business District

CBD diadakan dengan sistem multiyears dan berkesinambungan, artinya dilakukan 
anggaran per tahun. Proyeknya dari pembebasan sampai selesai dari tahun 2002-2012 sekarang. Tahap proyeknya meliputi pembebasan tanah pada tahun 2002-2009, pembangunan monumen, pembangunan jalan raya, dan tahap ke empat pembangunan fasilitas umum seperti terminal, bank daerah, pasar tugu pada hari minggu dan kantor imigrasi. Sedangkan pembangunan Hall baru selesai tahun 2012 ini. Hal ini masih diperlukan investor untuk pembangunan CBD karena keterbatasan dana dari pemerintah.

\section{2) Faktor Pendukung dan Penghambat dalam} Pembangunan Central Business District

\section{a) Faktor Pendukung dalam Pembangunan CBD}

(1) Adanya mandat yang diberikan oleh pemerintah kepada Kantor Penanaman Modal untuk melaksanakan tugas pokok dan fungsi, yaitu berdasarkan Peraturan Daerah Kabupaten Kediri Nomor 36 Tahun 2008 tentang Organisasi dan tata kerja Kantor Penanaman Modal.

(2) Adanya komitmen yang tinggi anggota organisasi terhadap organisasinya. Terdapat rasa memiliki organisasi yang kuat sehingga mendorong untuk melakukan kinerja yang lebih baik.

(3) Adanya jejaring yang telah terbangun dengan baik dengan instansi pemerintah lain. Dalam hal ini, KPM melakukan kerjasama dengan Kantor dagang Jerman dan Perancis, KPM pusat dan provinsi, dan pengusaha di daerah Jawa Timur.

(4) Pemerintah mudah dalam kerjasama, pemerintah memberikan kemudahan dalam perijinan membuka usaha serta penghapusan pajak hiburan penanam modal mendapat bantuan dalam hal promosi usaha dari pemerintah daerah.

\section{b) Faktor Penghambat dalam Pembangunan} CBD

(1) Masih belum adanya Pelayanan Terpadu Satu Pintu (PTSP) untuk semua jenis perijinan di Kabupaten Kediri yang bertujuan untuk mempermudah dan mempersingkat proses perijinan perusahaan di daerah serta membantu menngkatkan investasi di daerah.

(2) Masih kurangnya koordinasi antara instansi pemerintah pusat, daerah dan swasta yang menangani bidang penanaman modal seperti BKPM, BPM, dan KADIN.
(3) Belum adanya Peraturan Daerah tentang Penanaman Modal yang sesuai dengan Peraturan Perundang-undangan yang berlaku. Sampai saat ini masih dalam pembentukan Peraturan daerah tentang PTSP, Dewan Pengembangan Investasi Daerah dan SPSSE.

(4) Lingkungan belum terbentuk. Hanya masih ada satu penanam modal pada daerah SLG. Hal ini mengakibatkan investor belum tertarik untuk berinvestasi.

(5) Kondisi masyarakat yang masih rendah daya belinya, belum siap untuk mengonsumsi barang publik. Menjadi pertimbangan dalam penanaman modal.

\section{E. KESIMPULAN DAN REKOMENDASI}

\section{1) Kesimpulan}

Tujuan jangka panjang pembangunan Central Business District yaitu untuk penyediaan sarana publik, merangsang pertumbuhan investasi pada Kabupaten Kediri dan Terciptanya pertumbuhan ekonomi. Kebijakan jangka panjang pemerintah daerah Kabupaten Kediri pada pembangunan CBD yaitu dengan system multiyears/ berkesinambungan. Di anggarkan pada setiap tahun untuk pengembangannya.

\section{2) Rekomendasi}

Dengan adanya penganggaran yang bersifat multiyears dan berkesinambungan, hendaknya Pemerintah Kabupaten Kediri lebih menentukan waktu terselesaikannya pembangunan SLG. Pemerintah dapat merencanakannya dalam pembangunan jangka menengah atau jangka panjang. Pendanaan pembangunan dapat lebih dikoordinasikan dengan pemerintah pusat melalui block grant. Hendaknya, tujuan jangka panjang SLG dapat tercapai yaitu untuk kepentingan perekonomian masyarakat

\section{F. REFERENSI}

Asmoko, Hindri. Manajemen Strategis Pada Pemerintah Daerah: Inovasi Birokrasi Profesional. 2009. www.bppk.depkeu.go.id

Indardi, Sjamsiar Sjamsuddin. 2008. Administrasi Pemerintahan Lokal. Malang: Agritek YPN

Kantor Penanaman Modal Kabupaten Kediri. 2011. Program Kerja Kantor Penanaman Modal 2012. Pemerintah Kabupaten Kediri

Leo, Agustino. 2008. Dasar-Dasar Kebijakan Publik. Bandung: Alfabeta

Muluk , Khairul. 2005. Desentralisasi dan Pemerintah Daerah. Malang: Bayumedia Publishing 


\section{MEDIA5DSIAN}

Jurnal Ilmu Sosial dan Ilmu Administrasi Negara Vol. 1 No. 2

Moleong, Lexy J. 2008. Metode Penelitian Kualitatif. Jakarta: Bumi Aksara

Nugraha, Qudrat. 2014. “Manajemen Strategis Pengertian Manajemen Strategis." : 1-51. http://repository.ut.ac.id/4213/1/IPEM4218M1.pdf.

Peraturan Pemerintah Nomor 44 Tahun 1997 tentang Kemitraan
Peraturan Pemerintah Nomor 66 Tahun 2001 tentang Retribusi Daerah

Undang-undang Nomor 32 Tahun 2004 tentang Pemerintah Daerah

Undang-undang Nomor 25 Tahun 2007 tentang Penanaman Modal

Widodo, Joko. 2017. Analisis Kebijakan Publik. Malang: Media Nusa Creative 